\title{
Bioterror tester kits trouble federal agencies
}

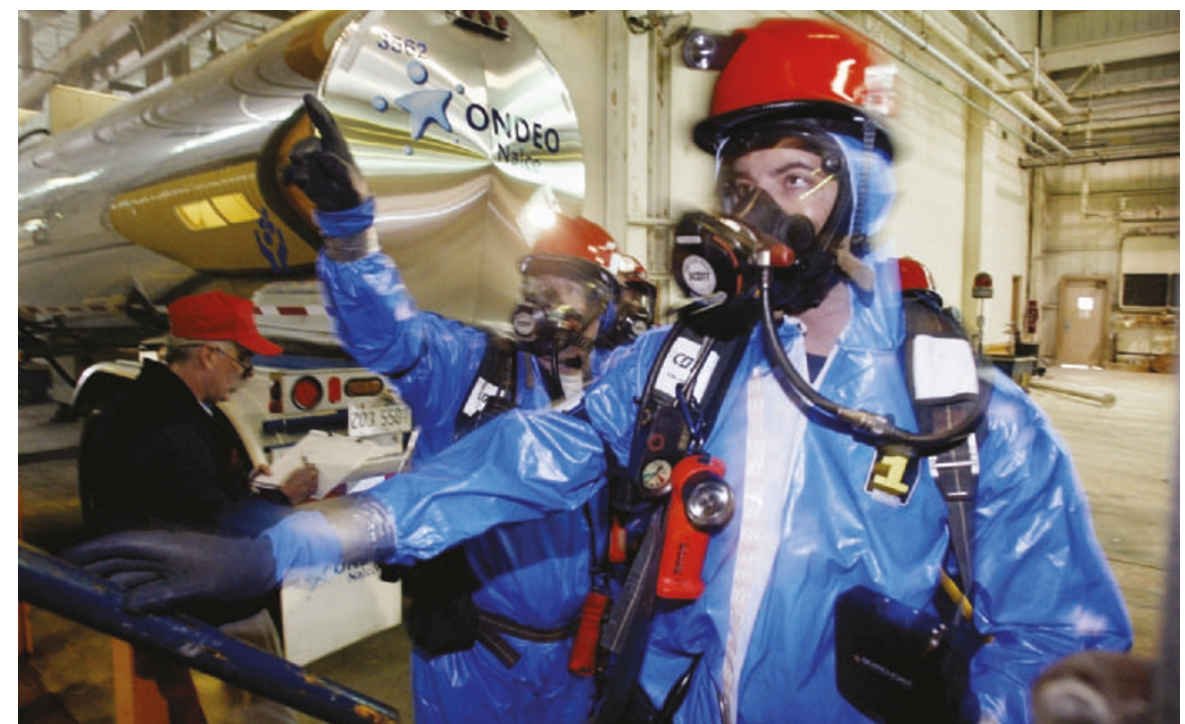

Test cases: emergency workers say they need kits to make faster checks for dangerous pathogens.

\section{Erika Check, Washington}

The US Department of Homeland Security (DHS) is running a $\$ 1.5$-million programme to evaluate hand-held kits used by emergency workers to test for biological hazards in possible terrorism situations.

The programme is the latest of several major federal efforts to evaluate the kits over the past two years. The kits are used by first responders - workers who are first on the scene in any emergency - who need to determine quickly whether a suspicious substance contains a pathogen such as anthrax. The programme will set operating standards and test which devices meet them.

Such kits are controversial, and battles over their use illustrate the technical challenges and difficulties in coordinating federal agencies that the US government faces as it tightens homeland security.

The government first focused on the kits in late 2001, after a terrorist mailed anthrax spores around the country. These highprofile attacks were followed by tens of thousands of 'powder calls' - most of which were false alarms. To distinguish fake calls from real ones quickly, emergency workers began using hand-held detectors. But federal officials were unsure about the accuracy of the devices, so the FBI and the Centers for Disease Control and Prevention in Atlanta, Georgia, both ran tests on them.

The results alarmed the US government's science advisers. On 19 July 2002, John Marburger, head of the White House Office of Science and Technology Policy (OSTP), announced in a memorandum that commercial hand-held detectors were plagued by technical problems and advised first responders and government officials not to use them. Marburger said the kits were prone to delivering false positive results, which could result in costly and frightening quarantines and city shut-downs.
This announcement angered some emergency workers, who say they know the limitations of the kits and combine them with other techniques to rule out false positives. They also say that the government's advice - that first responders rely only on laboratory tests - is not practical.

"The hand-helds can rule out a lot of things so, potentially, we do not have to quarantine people on a train for 72 hours while we wait for an answer," says John Eversole, chair of the International Association of Fire Chiefs' Committee on Hazardous Materials.

The manufacturers of the devices were also upset, because they say the first evaluation of hand-held kits took place behind closed doors, without their input.

Last year, the DHS and the OSTP began new evaluations. They set up a committee to oversee the tests under the auspices of the Association of Analytical Communities, based in Gaithersburg, Maryland. The committee comprises academics, government officials and industry representatives.

But controversy remains as manufacturers are worried that the tests will be biased by the OSTP's earlier conclusions and say the government is out of touch with everyday situations faced by first responders. "There is significant tension between the guy in the field and the bureaucracy," notes William Nelson, chief executive of Tetracore, a biotech company in Gaithersburg.

And scientists testing the devices remain concerned. "This product is toolimited," says Vincent Vilker, head of the biotechnology division at the National Institute of Standards and Technology, which is one of the agencies evaluating the results of the tests.

But with first responders clamouring for help, DHS and OSTP officials say they must provide guidance soon - at least until better kits come along. The new evaluations are expected to be available later this year.

\section{Rebelling scientists welcome left's landslide in France}

Declan Butler, Paris

French researchers protesting against the government over deep cuts to science funding emerged strengthened after last weekend's regional elections, which saw the ruling conservatives wiped off the map by a left-wing alliance.

The Socialist party, with their Green and Communist allies, took $50 \%$ of the vote - a score not seen since François Mitterrand's presidential victory in 1981. The Union pour un Mouvement Populaire, the party created by President Jacques Chirac in 2002 to unite the right, took $37 \%$ leaving it with only
Alsace; previously, the party held 14 of France's 22 regions.

Mass demonstrations by researchers in the run up to the election contributed to the vote against Prime Minister Jean-Pierre Raffarin. The revolt hit a public nerve, symbolizing what was wrong with the administration.

"The unprecedented protests by researchers played a significant part in the results of the elections, something never seen in recent history," says Vincent Courtillot, a geophysicist at the Paris Geophysical Institute, on the Jussieu campus in Paris. Courtillot should know. He was principal adviser to the minister for national education and research Claude Allègre who, following a smaller scientists' uprising in 2000, was simply sacked (see Nature 404, 421; 2000).

Courtillot is now optimistic about progress. Never before have researchers been so united on the shape of needed reforms, he points out (see Nature 428, 105; 2004). "A significant fraction of requests stand a better chance of being heard now," he says.

Chirac is expected to hold on to Raffarin, at least until June elections to the European Parliament, but to implement a thorough government reshuffle. 